\title{
A multimorbiditás hatása a funkcionális és életminőség-eredményekre generalizált osteoarthrosisban
}

\author{
Kővári Eszter dr. ${ }^{1}$ - Kaposi Ambrus dr. ${ }^{2}$ - Kiss Zsuzsanna dr. ${ }^{3}$ \\ Kurucz Réka dr. ${ }^{4}$. Mandl Péter dr. ${ }^{5}$ - Bálint Géza Péter dr. ${ }^{4}$ \\ Poór Gyula dr. ${ }^{4}$ - Szendrői Miklós dr. ${ }^{6}$ - Bálint Péter Vince dr. ${ }^{4}$ \\ ${ }^{1}$ Semmelweis Egyetem, Doktori Iskola, Budapest \\ ${ }^{2}$ Eötvös Loránd Tudományegyetem, Programozási Nyelvek és Fordítóprogramok Tanszék, Budapest \\ ${ }^{3}$ Semmelweis Egyetem, Általános Orvostudományi Kar, Budapest \\ ${ }^{4}$ Országos Reumatológiai és Fizioterápiás Intézet, Budapest \\ ${ }^{5}$ Medical University of Vienna, Division of Rheumatology, Vienna, Austria \\ ${ }^{6}$ Semmelweis Egyetem, Általános Orvostudományi Kar, Ortopédiai Klinika, Budapest
}

\begin{abstract}
Bevezetés: Az osteoarthrosis (az angol nevezéktanban osteoarthritis) mint a leggyakoribb ízületi megbetegedés kiemelt népegészségügyi jelentőséggel bír.

Célkitüzés: A multimorbiditás hatásának vizsgálata a funkcionális és életminôségtesztekre generalizált osteoarthrosisban (GOA, kéz- és térdízületi osteoarthrosis együttes jelenléte) szenvedő nókben.

Módszer: $A$ keresztmetszeti vizsgálatba az American College of Rheumatology (ACR) kritériumrendszere alapján klasszifikálható kéz- és térdízületi osteoarthrosisban szenvedő betegeket vontunk be. A kontrollcsoportba mozgásszervi szempontból panaszmentesek kerülhettek, akiknél klasszifikálható osteoarthrosis vagy gyulladásos reumatológiai betegség gyanúja nem merült fel. A multimorbiditást összegzett komorbiditásszámmal jellemeztük. A GOA-csoportban a funkciót Western Ontario and McMaster Universities Arthritis Index (WOMAC), a Cochin Hand Scale, Knee Injury and Osteoarthritis Outcome Score (KOOS) és a Health Assessment Questionnaire (HAQ) segítségével, míg az életminőséget mindkét csoportban EuroQol-5D Scale teszttel mértük. Elemeztük az összegzett komorbiditásszám, az életkor és a testtömegindex (BMI) közötti kapcsolatot. Az adatok elemzéséhez leíró statisztikai módszereket, kétmintás t-próbát és Pearson-féle korrelációs tesztet alkalmaztunk.

Eredmények: A vizsgálati csoportokba 200-200 résztvevőt vontunk be. Szignifikáns összefüggést mértünk mindkét vizsgálati csoportban a magasabb komorbiditásszám, a rosszabb életminőséget jelző EuroQol-5D-értékek, az idősebb életkor (korreláció a GOA-csoportban: $0,37, \mathrm{p}<0,001$, a kontrollcsoportban: $0,24, \mathrm{p}<0,001$ ) és a nagyobb BMI-érték között (korreláció a GOA-csoportban: 0,18, p: 0,01, a kontrollcsoportban: 0,45, p<0,001). Az összegzett komorbiditásszám emelkedése a GOA-csoportban negatív hatással volt a funkcióra és az életminőségre.

Következtetés: Az idősebb életkor és a növekvő BMI-érték kifejezetten erős összefüggést mutatott a multimorbiditással mindkét vizsgálati csoportban. A kontrollcsoporthoz képest gyengébb kapcsolat igazolódott a BMI és az összegzett komorbiditásszám között osteoarthrosisos betegek esetében. További vizsgálat szükséges a GOA-csoportban feltételezhető eltérő összefüggések miatt.
\end{abstract}

Orv Hetil. 2020; 161(32): 1332-1340.

Kulcsszavak: térd, kéz, osteoarthrosis, multimorbiditás, funkcionális, életminőség

\section{The effect of multimorbidity on functional and quality of life outcomes in women with generalized osteoarthritis}

Introduction: Osteoarthritis $(\mathrm{OA})$ as the most common joint disease is a major public health concern.

Aim: To investigate the effect of multimorbidity on functional and quality of life outcomes in women with generalized osteoathritis (hand and knee arthritis, GOA).

Method: In this cross-sectional study, patients according to the American College of Rheumatology (ACR) criteria for OA were invited. The control group consisted of subjects without any musculoskeletal symptoms, osteoarthritis or inflammatory rheumatic disease. Comorbidity count was calculated from the investigated comorbidities. In the GOA 
group, the function was assessed by Western Ontario and McMaster Universities Arthritis Index (WOMAC), Cochin Hand Scale, Knee Injury and Osteoarthritis Outcome Score (KOOS), Health Assessment Questionnaire (HAQ), while quality of life was measured in both groups with the EuroQol-5D Scale. Interaction between summarized comorbidity count, age, body mass index (BMI) and scores were analysed. Descriptive statistics, two-sample t-test and Pearson's correlation test were used for data analysis.

Results: The study groups included 200-200 participants with a similar age spread. Significant correlation was demonstrated in both study groups between higher comorbidity count and older age $(0.37, \mathrm{p}<0.001$, and $0.24, \mathrm{p}<0.001$ in the GOA and the control group, respectively) and higher BMI $(0.18, \mathrm{p}: 0.01$, and $0.45, \mathrm{p}<0.001$ in the GOA and the control group, respectively). In GOA, the increasing comorbidity number had a negative effect on the measured outcomes.

Conclusions: Age and BMI showed strong correlation with multimorbidity in both groups. The lower correlation between BMI and comorbidity count in the GOA group requires further investigation and may suggest different interactions.

Keywords: knee, hand, osteoarthritis, multimorbidity, functional, quality of life

Kővári E, Kaposi A, Kiss Zs, Kurucz R, Mandl P, Bálint GP, Poór Gy, Szendrői M, Bálint PV. [The effect of multimorbidity on functional and quality of life outcomes in women with generalized osteoarthritis]. Orv Hetil. 2020; 161(32): 1332-1340.

(Beérkezett: 2020. március 11.; elfogadva: 2020. április 9.)

\begin{abstract}
Rövidítések
ACR $=($ American College of Rheumatology $)$ Amerikai Reumatológiai Kollégium; BMI = (body mass index) testtömegindex Cochin $=($ Cochin Hand Functional Scale $)$ kéz funkcionális skála; ETT-TUKEB = Egészségügyi Tudományos Tanács - Tudományos és Kutatásetikai Bizottság; EQ-5D-3L = (EuroQol-5D-3L) EuroQol életminőségi kérdőív; EQ-5D-3L TTO-UK = az EuroQol kérdő́iv eredménye a brit mintapopulációhoz viszonyítva; GDP = (gross domestic product) bruttó hazai termék; GOA = generalizált osteoarthrosis; HAQ = (Health Assessment Questionnaire) egészségfelmérő kérdőív; KOOS $=($ Knee Injury and Osteoarthritis Outcome Score $)$ térdsérülések és osteoarthritis kimenetele teszt; $\mathrm{n}=$ fó; $\mathrm{OA}=$ (osteoarthritis) osteoarthrosis; $\mathrm{r}=$ korrelációs együttható; $\mathrm{SD}=$ standard deviáció; SF-36 = (36-Item Short Form Health Survey) 36 tételből álló rövid egészségiállapot-felmérés; VAS = vizuális analóg skála; WOMAC = Western Ontario and McMaster Universities Osteoarthritis Index
\end{abstract}

Az osteoarthrosis (OA, az angol nevezéktanban osteoarthritis) a leggyakoribb ízületi betegség, amely a legtöbbször a térd-, a csípő- és a kézkisízületet betegíti meg. Az osteoarthrosis egészséggazdasági jelentősége világszerte kiemelkedő: felmérések szerint a fejlett országokban a bruttó hazai termékből (GDP) kivett költségek 1,0\%-ról 2,5\%-ra emelkedtek [1, 2]. Becslések szerint 60 év felett a férfiak 10\%-a, a nók 18\%-a tüneteket okozó OA-ban szenved [3]. Az osteoarthrosisban szenvedőknél magas komorbiditásszám mérhető [4]. A komorbiditások befolyásolják a kezelési stratégiát, a mortalitást, az egészségügyi költségeket [5], hatással vannak a sebészeti terápia túlélési és sikerességi adatainak alakulására [6].

A népesség életkorának növekedésével a multimorbiditás (két vagy több krónikus betegség együttes fennállá- saként definiálva) előfordulása egyre inkább általánosnak nevezhető [7]. Az obesitas az életkor emelkedésével szintén magas gyakoriságú, amely a multimorbiditással kapcsolatban is fontos tényezőnek tekinthető [8]. Az elhízással összefüggésbe hozható betegségek száma igazoltan kifejezetten magas [9].

A multimorbiditással foglalkozó kutatásokban az együttesen előforduló betegségek, az életkor, a kezelési lehetőségek és a szervi károsodások közötti kapcsolat elemzése kiemelt fontosságú [10].

Generalizált osteoarthrosison (GOA) a betegség sokízületet érintő (polyarticularis) formáját értjük. Annak ellenére, hogy az osteoarthrosis ezen fenotípusa kiemelt jelentőségú, relatíve keveset tudunk a GOA-ban szenvedők funkcionális és életminőség-eredményeiről.

Vizsgálatunk célja a multimorbiditás hatásának elemzése a funkcionális és életminőségtesztek alakulására.

Az előzőek mellett vizsgáltuk az összegzett komorbiditásszám, az életkor és a testtömegindex (BMI) közötti összefüggéseket a beteg- és a kontrollcsoportban.

\section{Módszer}

\section{Vizsgálati kialakitás}

A vizsgálat multicentrikus, megfigyelésen alapuló és keresztmetszeti felépítésű. A kutatást az ETT TUKEB (regisztrációs szám: 4/2015/EKU) engedélyével végeztük el, amely biztosította a hatályos etikai elvárások és a kutatásra vonatkozó szabályok betartását. A vizsgálati résztvevók bevonása 2015. március és 2016. április között történt. Az eltérő súlyosságú betegek bevonásának biztosítása miatt a vizsgálathoz különböző súlypontú intézményeket választottunk. Tercier (a legmagasabb és 
feltételezhetően legsúlyosabb betegek ellátását végző) központként az Országos Reumatológiai és Fizioterápiás Intézetet (Budapest), szekunder ellátási központként pedig a Petz Aladár Megyei Oktató Kórház Reumatológiai Osztályát (Győr) választottuk. A kontrollcsoport tagjait a primer ellátórendszerben választottuk ki.

\section{A beteg-és a kontrollcsoport kialakitása}

A GOA-csoportra vonatkozó bevonási kritériumok a következők voltak: térd- és kézkisízületi osteoarthrosis együttes előfordulása az ACR klinikai kritériumrendszerének megfelelően $[11,12], 18$ év vagy annál idősebb életkor és a vizsgálati beleegyező nyilatkozat aláírása. Kizáró feltételnek tekintettük a már klasszifikált vagy az anamnézis áttekintése/fizikális vizsgálat során felmerülő gyulladásos reumatológiai betegséget és a magyar nyelv nem anyanyelvi szintü megértését. A betegek vizsgálatát minimum két orvos végezte, egymás utáni napokon. A betegeket a vizsgálatba csak megegyező klinikai vélemény esetén vontuk be.

A kontrollcsoport kialakítását - beleértve az anamnézis felvételét és a fizikális vizsgálat elvégzését - reumatológiai területen dolgozó orvos végezte a háziorvos segítségével. A bevonási kritériumok között szerepelt a 18 év vagy idősebb életkor és az írásos beleegyező nyilatkozat.

Kizárási kritériumnak tekintettünk bármiféle mozgásszervi panaszt, osteoarthrosist, gyulladásos reumatológiai betegséget és a magyar nyelv nem anyanyelvi szintü megértését.

A vizsgálati résztvevőknél az aktuális testmagasság- és testtömegadatokból BMI-értéket számoltunk [13].

\section{Demográfiai és komorbiditásadatok}

A vizsgált komorbiditások kijelölésekor figyelembe vettük az aktuális komorbiditásvizsgálatokban elemzett betegséglistákat [14-17]. A multimorbiditást nem diszkrét változóként kezeltük, hanem a vizsgált komorbiditásokból minden vizsgálati résztvevőre összegzett komorbiditásszámot kalkuláltunk (a fennálló betegségek összege).

Munkacsoportunk a korábbi publikációjában közölte a vizsgált komorbiditások listáját: elemeztük a cardiovascularis betegségek (hypertonia, ischaemiás szívbetegség, akut coronaria szindróma, hyperlipidaemia, tüdőembólia, alsó végtagi mélyvénás thrombosis, alsóvégtagi varicositas), a cerebrovascularis betegségek (tranziens ischaemiás attak, stroke), az endokrinológiai betegségek (1-es, 2-es típusú diabetes mellitus, euthyreoid struma, hyperthyreosis, hypothyreosis), az obstruktív tüdőbetegségek (asthma, krónikus obstruktív tüdőbetegség), a tumoros megbetegedések (melanoma malignum, méhnyakrák, rosszindulatú emlődaganat, myoma uteri, jóindulatú emlődaganat), a gyomor-bél rendszeri betegségek (colorectalis carcinoma, gastrooesophagealis refluxbetegség, diverticulosis, gyomorfekély, nyombélfekély), az egyéb neurológiai betegségek (primer fejfájás, polyneuropat- hia, vertebrobasilaris szindróma, benignus paroxysmalis positionalis vertigo, esszenciális tremor, Parkinson-betegség), a depresszió (kezelési stratégia szerint két csoportban), a vesekövesség, a mütéttel kezelt otosclerosis és az alvási apnoe szindróma gyakoriságát [18].

\section{Funkcionális és életminôségtesztek}

A GOA-csoportban a térdízületi funkciót Western Ontario and McMaster Universities Osteoarthritis Index (WOMAC) és Knee Injury and Ostearthritis Outcome Score (KOOS) segítségével [19], míg a kézfunkciót Cochin-teszttel mértük [20].

Az osteoarthrosisban szenvedők funkcionális állapotának jellemzésére Health Assessment Questionnaire (HAQ-) [21, 22] tesztet, a fájdalom felmérésére vizuális analóg skálát (VAS) alkalmaztunk. Az életminőséget mindkét csoportban EuroQol-5D (EQ-5D-3L) [23] kérdőívvel vizsgáltuk.

A szubjektív globális életminőséget VAS-skálával mértük 0 és 100 határértékek között, milliméteres beosztással. A magasabb érték a jobb életminőséget prezentálta. Az EQ-5D-3L, a KOOS-teszt és a VAS alapján mért szubjektív globális egészségi állapot esetében a nagyobb értékek kedvezőbb eredményt jelentettek, míg az alábbi funkcionális (WOMAC, Cochin, HAQ) és életminőség(szubjektív megítélésű fájdalomszint) teszteknél a magasabb értékek rosszabb eredményt tükröztek. Statisztikai elemzésünk elkészítésekor a magyar populációra jellemző preferenciaérték hiányában az EQ-5D-indexet a brit mintapopulációhoz (EQ-5D TTO-UK: értékkészlete $(-0,5694)-1$; a magasabb érték a jobb életminőségre utal), a teszt VAS-score-értékét az európai referenciaértékhez (EQ-5D VAS score Europe) vonatkoztattuk [24].

\section{Statisztikai analizis}

Az összegzett komorbiditásszámot a 37 vizsgált komorbiditásból határoztuk meg (a fennálló betegségek szummációja) a vizsgálat minden résztvevőjénél. A GOA- és a kontrollcsoport közti különbségek leírásához leíró statisztikai módszereket alkalmaztunk. A folytonos adatok jellemzését átlagos és standard deviációval (SD), diszkrét változóknál előfordulási gyakorisággal adtuk meg. A BMI és az életkor normáleloszlását mindkét vizsgálati csoportban 'quantile-quantile plot' módszerrel ellenőriztük. A két vizsgálati csoport életkor- és BMI-értékeit kétmintás t-próbával vetettük össze. Az obesitas előfordulási gyakoriságát kategorikus változóként Fisher-féle egzakt teszttel elemeztük.

Az összegzett komorbiditásszám, a szubjektív életminőségre vonatkozó VAS-érték, valamint az EQ-5D TTO-UK és az EQ-5D VAS-teszt-érték esetében a vizsgálati csoportok közötti különbséget Wilcoxon-féle rangteszttel adtuk meg. 


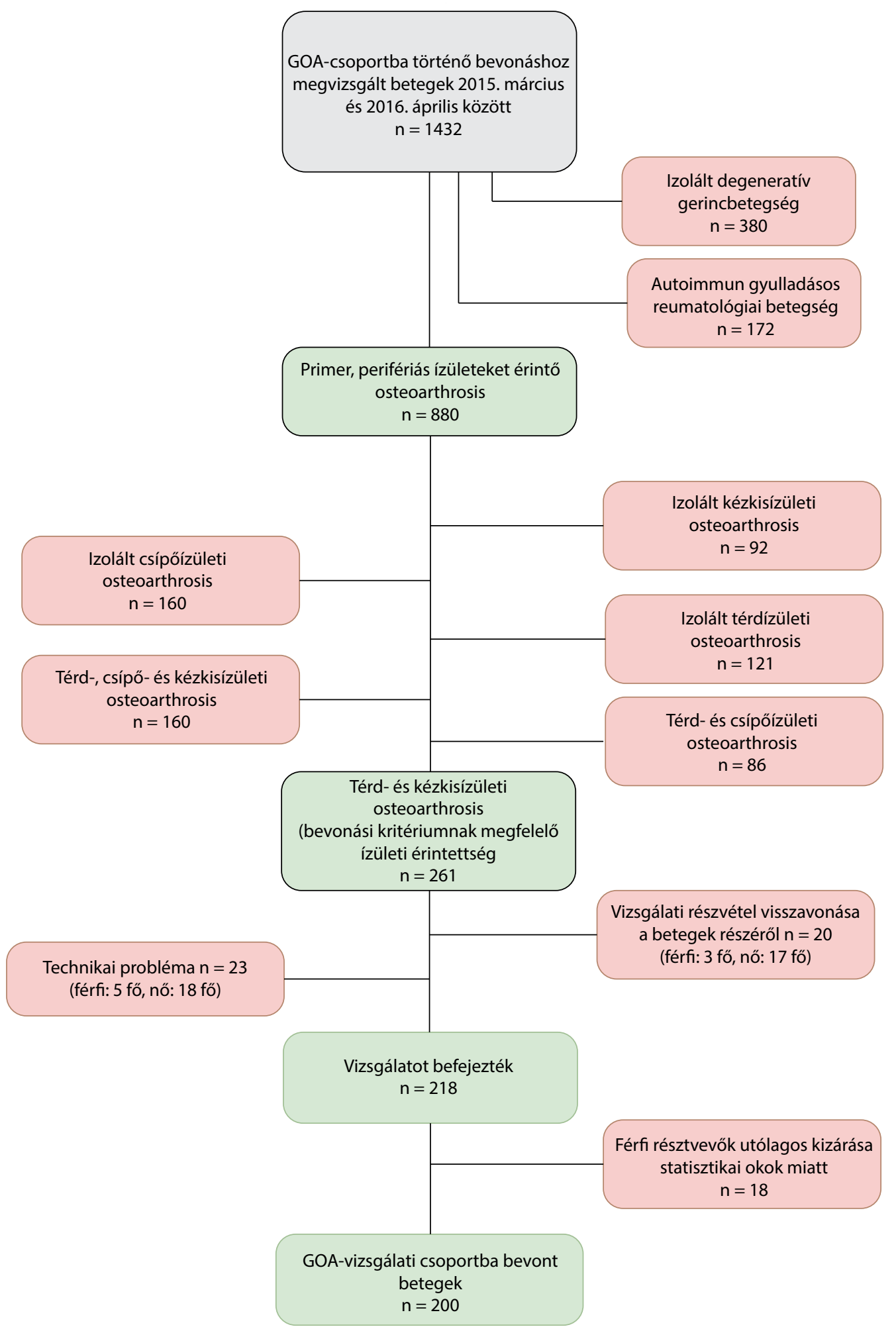

1. ábra

$\mid \begin{aligned} & \text { A GOA-vizsgálati csoport kialakítása } \\ & \text { GOA = generalizált osteoarthrosis; } \mathrm{n}=\text { fó }\end{aligned}$

Az összegzett komorbiditásszám és a dependens változók elemzését Pearson-féle korrelációs teszttel végeztük el külön-külön a vizsgálati csoportokban. Az $\mathrm{R}^{2}$ - és a korrigált $\mathrm{R}^{2}$-értékeket a lineáris regresszióból kaptuk meg. Dependens változóként vizsgáltuk az alábbiakat: életkor, BMI, szubjektív globális életminőség és a fájdalom jellemzésére felvett VAS-érték, EQ-5D-indexek, HAQ-, WOMAC-, KOOS- és Cochin-féle funkcionális 
teszt. A szignifikanciaszintet $\mathrm{p}<0,05$-nél állapítottuk meg, a statisztikai elemzéshez $\mathrm{R}$ programot (3.2.3 verzió 2015-12-10) használtunk.

\section{Eredmények}

\section{A vizsgálati csoportok demográfiai adatai}

A GOA-csoport kialakításához 1432 potenciális személyt vizsgáltunk meg, akik közül 261 fő felelt meg a bevonási kritériumoknak (10\% férfi, 90\% nő), és végül 218 fó fejezte be a vizsgálatot. A GOA-csoportba történő bevonás a legtöbbször a bevonási kritériumoknak nem megfelelő perifériás ízületi érintettség miatt nem történhetett meg (1. ábra).

A kontrollcsoportba történő bevonási folyamatot a 2. ábra mutatja. Mivel a bevonási kritériumoknak megfelelő férfi vizsgálati résztvevők száma nagyon alacsony volt, a pontosabb statisztikai elemzés érdekében végül csak a női vizsgálati résztvevők eredményét elemeztük, kialakítva így a 200-200 fös GOA- és illesztett kontrollcsoportot.

A két vizsgálati csoportban részt vevők átlagéletkora megegyezett $(65,47 \pm 9,85)$. Az átlagos BMI-érték a GOA-csoportban szignifikánsan magasabb volt (GOA: $29,13 \pm 5,42$, kontrollcsoport: $26,80 \pm 4,73, \mathrm{p}<0,001)$, ahogyan az obesitas gyakorisága is (GOA: $42 \%$, kontrollcsoport: 29,5 \%, p: 0,01, 1/a táblázat).

\section{Az összegzett komorbiditásszám, az életminôség- és funkcionális tesztek evedményei közötti összefüggés}

Az összegzett komorbiditásszám tekintetében szignifikáns eltérést találtunk a két vizsgálati csoport között. A GOA-betegek majdnem kétszer annyi komorbiditásban szenvedtek, mint a kontrollcsoport tagjai (átlagos komorbiditásszám GOA: $5,52 \pm 2,55$, kontrollcsoport: $2,80 \pm 2,51, \mathrm{p}<0,001)$.

$\mathrm{Az}$ életminőségtesztek eredményei szignifikánsan rosszabbak voltak a GOA-csoportban. A kontrollcso-

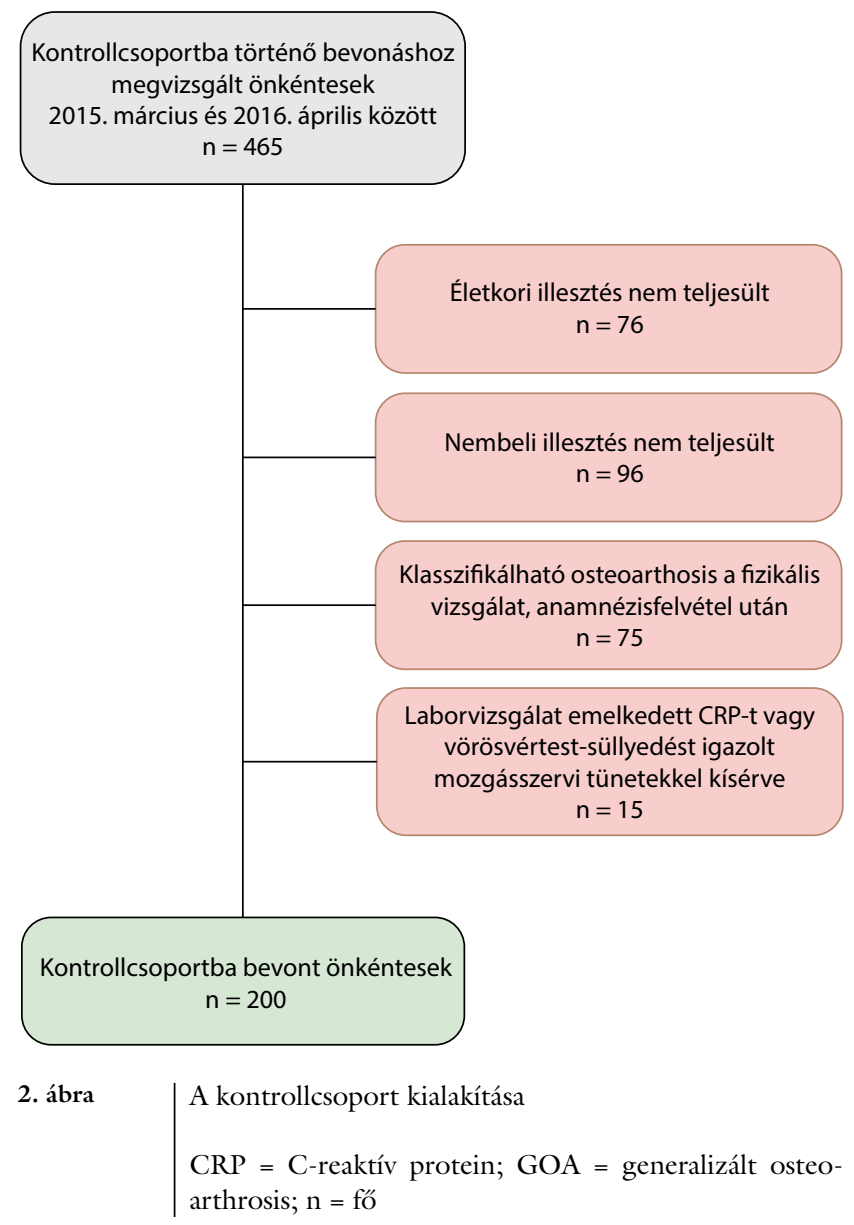

porttal összehasonlítva az EQ-5D-3L (GOA: 0,42 \pm $0,36$, kontrollcsoport: $0,80 \pm 0,22)$ és a globális egészségi állapotra vonatkozó értékek (GOA: 59,85 \pm 20,98, kontrollcsoport: 73,78 $\pm 17,10, \mathrm{p}<0,001)$ szignifikánsan rosszabb eredményt igazoltak a GOA-csoportban. A GOA-csoport utóbbi értékei alig haladták meg a VASskálán felvehető középértéket $(59,85 \pm 20,98)$, míg a kontrollcsoport értékei a felső kategóriába estek (73,78 $\pm 17,10$ ), utalva az előnyösebb egészségmegítélésre.

A magasabb összegzett komorbiditásszámú vizsgálati résztvevők mindkét csoportban rosszabb szubjektív

1/a táblázat | Az életkor, a BMI-megoszlás, az obesitas és az életminőségtesztek alakulása a két vizsgálati csoportban

\begin{tabular}{|c|c|c|c|}
\hline & GOA & Kontrollcsoport & p-érték \\
\hline $\mathrm{n}$ & 200 & 200 & \\
\hline Életkor (év), átlag \pm SD & $65,47 \pm 9,85$ & $65,47 \pm 9,85$ & 1,00 \\
\hline $\mathrm{BMI}\left(\mathrm{kg} / \mathrm{m}^{2}\right)$, átlag $\pm \mathrm{SD}$ & $29,13 \pm 5,42$ & $26,80 \pm 4,73$ & $<0,001$ \\
\hline Az obesitas prevalenciája, n (\%) & $\mathrm{n}=84(42 \%)$ & $\mathrm{n}=59(29,5 \%)$ & 0,01 \\
\hline Összegzett komorbiditásszám, átlag \pm SD & $5,52 \pm 2,55$ & $2,80 \pm 2,51$ & $<0,001$ \\
\hline A szubjektív életminőség-megítélés VAS-skálán mért értéke, átlag \pm SD & $59,85 \pm 20,98$ & $73,78 \pm 17,10$ & $<0,001$ \\
\hline EQ-5D-3L TTO-UK, átlag \pm SD & $0,42 \pm 0,36$ & $0,80 \pm 0,22$ & $<0,001$ \\
\hline
\end{tabular}

BMI = testtömegindex; EQ-5D-3L = EuroQol életminőségi kérdőív; EQ-5D-3L TTO-UK = az EuroQol-teszt eredménye a brit mintapopulációhoz viszonyítva; GOA = generalizált osteoarthrosis; $\mathrm{n}=$ fó; $\mathrm{SD}=$ standard deviáció; VAS = vizuális analóg skála 
1/b táblázat | Korrelációs eredmények az összegzett komorbiditásszám és a két vizsgálati csoportban mért változók között

\begin{tabular}{|c|c|c|c|c|c|}
\hline & & $\mathrm{R}^{2}$ & Illesztett $\mathrm{R}^{2}$ & Korreláció & p-érték \\
\hline \multirow[t]{2}{*}{ Életkor } & GOA & 0,14 & 0,13 & 0,37 & $<0,001$ \\
\hline & Kontroll & 0,06 & 0,05 & 0,24 & $<0,001$ \\
\hline \multirow[t]{2}{*}{ BMI } & GOA & 0,03 & 0,03 & 0,18 & 0,01 \\
\hline & Kontroll & 0,21 & 0,20 & 0,45 & $<0,001$ \\
\hline \multirow{2}{*}{$\begin{array}{l}\text { A szubjektív életminőség-megítélés VAS-skálán mért } \\
\text { értéke }\end{array}$} & GOA & 0,29 & 0,28 & $-0,54$ & $<0,001$ \\
\hline & Kontroll & 0,11 & 0,10 & $-0,33$ & $<0,001$ \\
\hline \multirow[t]{2}{*}{ EQ-5D-3L TTO-UK } & GOA & 0,032 & 0,03 & $-0,18$ & 0,01 \\
\hline & Kontroll & 0,14 & 0,14 & $-0,37$ & $<0,001$ \\
\hline \multirow{2}{*}{$\begin{array}{l}\text { EQ-5D-3L szubjektív életminőség-megítélés a „Europe” } \\
\text { mintapopulációhoz viszonyítva }\end{array}$} & GOA & 0,05 & 0,04 & $-0,22$ & 0,002 \\
\hline & Kontroll & 0,11 & 0,10 & $-0,33$ & $<0,001$ \\
\hline
\end{tabular}

BMI = testtömegindex; EQ-5D-3L = EuroQol életminőségi kérdő́iv; EQ-5D-3L TTO-UK = az EuroQol-teszt eredménye a brit mintapopulációhoz viszonyítva; GOA = generalizált osteoarthrosis; VAS = vizuális analóg skála
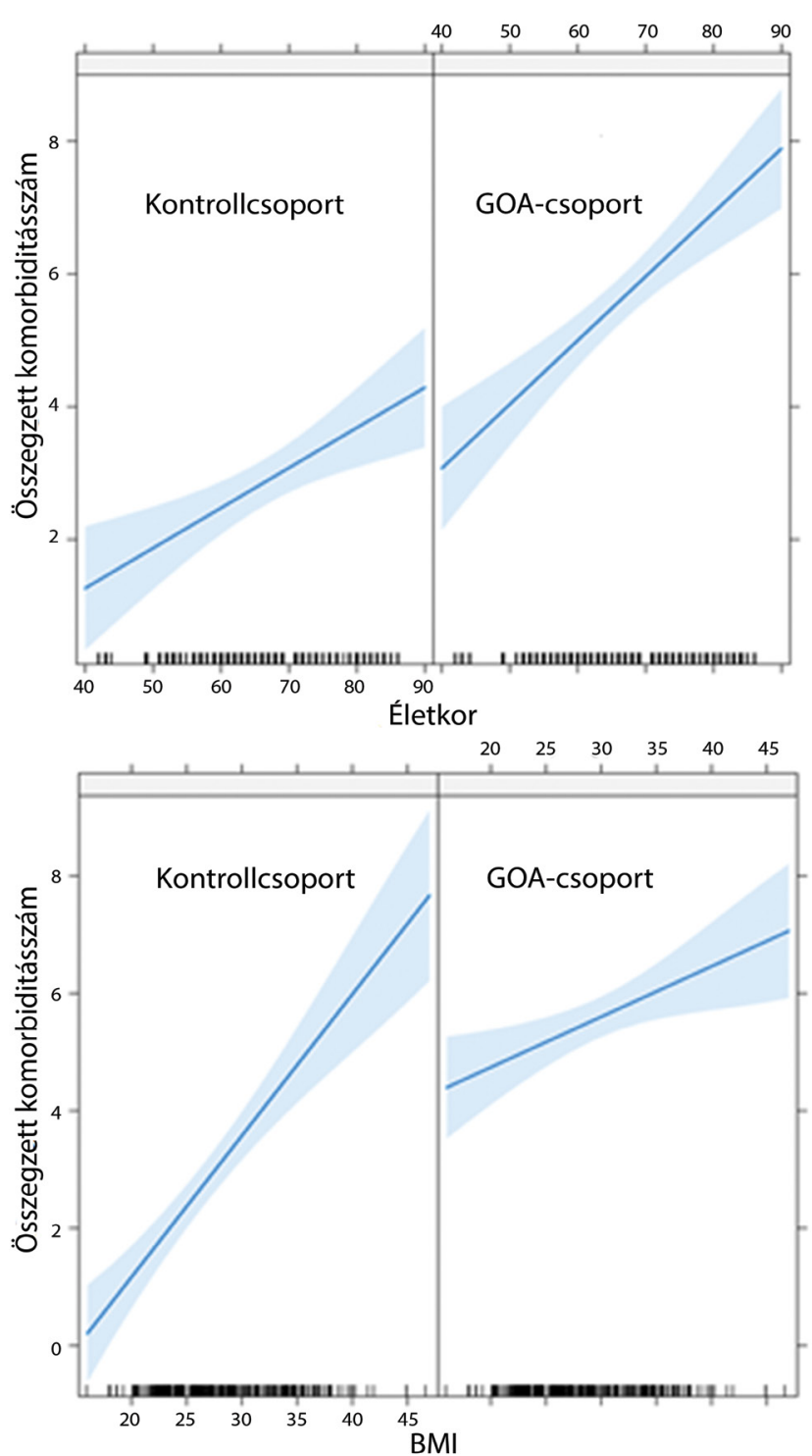

3. ábra
Az összegzett komorbiditásszám, az életkor (felül) és a BMIérték (alul) közötti összefüggés a kontroll- és a GOA-csoportban

$\mathrm{BMI}=$ testtömegindex $; \mathrm{GOA}=$ generalizált osteoarthrosis egészségi állapotról számoltak be - korrelációs együttható (r) GOA: $-0,54$, kontrollcsoport: $-0,33, \mathrm{p}<0,001$. A komorbiditásszám emelkedésével mind a GOA-, mind a kontrollcsoportban alacsonyabb életminőséget jelentő EQ-5D-3L-értéket mértünk. A multimorbiditás a GOAcsoportban gyengébb korrelációt mutatott az EQ-5D TTO UK (GOA: r: $-0,18$, p: 0,01, kontrollcsoport: $\mathrm{r}:-0,37, \mathrm{p}<0,001)$ és az EQ-5D szerinti VAS-értékekkel (GOA: r: $-0,22, \mathrm{p}: 0,002$, kontrollcsoport: $\mathrm{r}:-0,33$, $\mathrm{p}<0,001)(1 / b$ táblázat $)$.

Az idősebb életkor (GOA: r: 0,37, kontrollcsoport: $r$ : $0,24$, mindkét csoportra $\mathrm{p}<0,001)$ és a magasabb BMIérték (GOA: r: 0,18, p: 0,01, kontrollcsoport: r: 0,45, $\mathrm{p}<0,001)$ mindkét vizsgálati csoportban összefüggést mutatott a magasabb összegzett komorbiditásszámmal. Érdekes eredményként a BMI-értékkel erősebb összefüggést találtunk a kontrollcsoportban ( $1 / b$ táblázat, 3. ábra).

\section{Funkcionális eredmények a GOA-csoportban}

A GOA-csoportban felvett funkcionális tesztek eredményét a $2 / a$ táblázat tartalmazza.

Erős összefüggést igazoltunk a növekvő összegzett komorbiditásszám és a rosszabb funkcionális eredmények között, különösképpen a térdízületre vonatkoztatva $(2 / b$ táblázat).

A multimorbiditással kapcsolatban a KOOS-teszt kissé szorosabb összefüggést mutatott (r: $-0,49)$ a WOMACteszttel $(\mathrm{r}: 0,34)$ mért értékekhez képest, de mindegyik eredmény szignifikáns volt. A magasabb komorbiditásszám gyengébb kapcsolatot tükrözött a kézfunkcióval (r: $0,29, \mathrm{p}<0,001)$, mint a térdízületi funkcionális eredményekkel.

A HAQ-értékek kifejezetten erős korrelációt mutattak a növekvő komorbiditásszámmal ( $\mathrm{r}: 0,47, \mathrm{p}<0,001)$ a GOA-csoportban. Valamivel gyengébb kapcsolatot (r: 0,20, p: 0,004) mértünk az önbevallásos fájdalomintenzitás és a magasabb komorbiditásszám között. 
2/a táblázat $\mid$ Az OA-ra specifikus funkcionális tesztek eredményei a GOAcsoportban

\begin{tabular}{lc}
\hline A GOA-csoportban mért teszt & Átlag \pm SD \\
\hline HAQ-teszt & $1,15 \pm 0,61$ \\
WOMAC-teszt & $941,75 \pm 401,43$ \\
KOOS-teszt & $50,77 \pm 12,53$ \\
Cochin-teszt & $8,89 \pm 9,26$ \\
\hline
\end{tabular}

Cochin-teszt = kéz funkcionális skála; GOA = generalizált osteoarthrosis; HAQ = egészségfelmérő kérdőív; KOOS = térdsérülések és osteoarthritis kimenetele teszt; $\mathrm{OA}=$ osteoarthrosis; $\mathrm{SD}=$ standard deviáció; WOMAC $=$ Western Ontario and McMaster Universities Osteoarthritis Index

2/b táblázat | Korrelációs eredmények az összegzett komorbiditásszám és a GOA-csoportban mért életminőség- és funkcionális tesztek eredményei között

\begin{tabular}{lcccc}
\hline A GOA-csoportban mért teszt & $\mathrm{R}^{2}$ & $\begin{array}{c}\text { Illesztett } \\
\mathrm{R}^{2}\end{array}$ & $\begin{array}{c}\text { Korrelá- } \\
\text { ció }\end{array}$ & p-érték \\
\hline HAQ-teszt & 0,22 & 0,22 & 0,47 & $<0,001$ \\
Fájdalom VAS-skálán mérve & 0,04 & 0,04 & 0,20 & 0,004 \\
WOMAC-teszt & 0,11 & 0,11 & 0,34 & $<0,001$ \\
KOOS-teszt & 0,24 & 0,24 & $-0,49$ & $<0,001$ \\
Cochin-teszt & 0,08 & 0,08 & 0,29 & $<0,001$ \\
\hline
\end{tabular}

Cochin-teszt = kéz funkcionális skála; GOA = generalizált osteoarthrosis, HAQ = egészségfelmérő kérdőív; KOOS = térdsérülések és osteoarthritis kimenetele teszt; VAS = vizuális analóg skála; WOMAC = Western Ontario and McMaster Universities Osteoarthritis Index

\section{Megbeszélés}

Vizsgálatunk összefüggést igazol a növekvő komorbiditásszám és a különböző funkcionális és életminőségtesztek között mind a kontroll-, mind a GOA-csoportban. A GOA-csoportban az átlagos összegzett komorbiditásszám majdnem a kétszerese a kontrollcsoportban mértnek. Eredményünk összhangban van a korábbi vizsgálatok eredményeivel $[4,6,18,25]$.

A GOA-csoportban az általános tesztek (EQ-5D és a szubjektív egészségmegítélés) szignifikánsan rosszabb életminőséget igazoltak. Az előbbi eredmények összevethetők korábbi vizsgálatok megállapításaival [26, 27], és alátámasztják, hogy a multimorbiditás fontos, életminőséget meghatározó faktornak tekinthetó $[28,29]$.

A multimorbiditás oka kifejezetten komplex [30]. Térdízületi osteoarthrosisban szenvedőknél kimutatták, hogy az életminőség függ a nemtől, a testtömegtől, a fizikai aktivitástól, a mentális egészségtől, a szociális-gazdasági helyzettől és az iskolázottságtól [31]. A nói betegek rosszabb életminőségrôl számoltak be a férfiakhoz képest mind a WOMAC [32], mind az SF-36 [33] fizikai korlátozottságot jellemző részértékeiben.

A fent említett faktorok közül a multimorbiditással kapcsolatban az obesitas és az idősebb életkor a legtöbb- ször kiemelt befolyásoló tényező. Vizsgálatunk igazolta, hogy a magasabb BMI-érték és az idősebb életkor mind a GOA-csoportban, mind a kontrollcsoportban magasabb komorbiditásszámmal járt. Előző eredményeink más munkacsoportok eredményeivel összehangban vannak $[34,35]$. A korábbiakban még nem publikált eredményként a BMI-értékkel kapcsolatban erősebb összefüggést mértünk a kontrollcsoportban. Generalizált osteoarthrosisban komplex kapcsolat feltételezhetó az osteoarthrosis, a társuló komorbiditások és a testtömeg alakulása között potenciális közös patofiziológiai folyamatok révén. Az elhízás jelentősége kiemelt: jól ismert, hogy az obesitas szignifikánsan alacsonyabb életminő" séggel jár. Igazolták azt is, hogy a testtömeg csökkenése az életminőséget jellemző értékek javulását eredményezi [36]. Hosszmetszeti vizsgálatban a testtömeg növekedése a multimorbiditás kialakulását $25 \%$-kal fokozta a stabil testtömeggel rendelkező vizsgálati résztvevőkhöz képest [37].

Az idősebb életkor a gyakrabban előforduló komorbiditások mellett alacsonyabb EQ-5D-3L-értékkel jár [38]. Ismertek különböző életkori csoportokra jellemző komorbiditási karakterisztikák [39]. Újabb tanulmányok azonban kiemelik a multimorbiditás növekvő előfordulását a középkorúak között is [40]. Mivel az idősebb életkor, a magasabb BMI-érték és a multimorbiditás is összefüggésben van az OA-val, kérdéses, hogy a komorbiditásszám (és a multimorbiditás) milyen összefüggésben van az életkorral és a BMI-értékkel.

A GOA-csoportban erôs összefüggést mértünk a komorbiditásszám és a funkcionális eredmények között, különösképpen a térdízületre vonatkozóan.

Ez a különbség magyarázható az esetlegesen eltérő fokú ízületi érintettséggel, de az is lehetséges, hogy a betegek a teherviselő és a nem teherviselő ízületeket eltérő prioritással ítélik meg.

Az osteoarthrosis klasszifikálható radiológiai és klinikai kritériumok alapján. Vizsgálatunkban az ACR klinikai klasszifikációs rendszerét használtuk. Svédországi vizsgálatban az ACR klinikai klasszifikációs kritériumainak megfelelő OA-betegek körében alacsonyabb életminőség-értékeket mértek, mint az ACR klinikai kritériumait nem teljesítő radiológiai OA-ban szenvedóknél [41].

A komorbiditásklaszterek vizsgálata viszonylag új módszer az OA-kutatásban. Munkacsoportunk korábbi publikációjában különböző komorbiditási klaszterekről számoltunk be generalizált osteoarthrosisban [18]. Más munkacsoportok a klaszterek előnytelen alakulásával szignifikáns összefüggést igazoltak az életkorral, a női nemmel, az alacsonyabb szociális és gazdasági helyzettel, a fennálló mentális problémákkal [42] és a nagyobb testtömeggel [43].

Vizsgálatunk korlátai a következők: a vizsgált populáció relatív kicsinek tekinthetố a szigorú bevonási kritériumok, a személyes adatfelvétel és a kontrollokkal történt illesztés miatt. Az egyes komorbiditásokkal nem elemez- 
tük az életminőség- és a funkcionális eredmények alakulását, a társuló betegségek súlyossági fokát nem adtuk meg. Az előzőek miatt további epidemiológiai klinikai kutatások szükségesek.

\section{Következtetés}

- Az általános egészségi mutatók szignifikánsan alacsonyabbak voltak a GOA-csoportban. Mind az EQ-5D, mind a szubjektív egészségi állapotot jelző VAS-értékek igazolták az osteoarthrosis betegségterhét.

- A növekvő komorbiditásszám mindkét vizsgálati csoportban rosszabb életminőség-értékekkel járt. A GOA-csoportban a szubjektív egészségi állapotra vonatkozó értékek kifejezetten erős korrelációt mutattak a multimorbiditással.

- Az idősebb életkor és a növekvő BMI-érték mindkét vizsgálati csoportban magasabb összegzett komorbiditásszámmal járt. A BMI-index tekintetében erôsebb összefüggést igazoltunk a kontrollcsoportban. Ez az eredmény további vizsgálatot igényel nagyobb vizsgálati csoporton. GOA esetén komplex összefüggés valószínúsíthető az osteoarthrosis, a komorbiditások és a testtömeg között, valószínúleg részben közös patofiziológiai folyamatok révén.

- A GOA-csoportban erős összefüggés igazolódott a növekvő komorbiditásszám és a károsodott funkcionális értékek között, különösképpen a térdízületre vonatkoztatva. A kézkisízületi funkcióval gyengébb öszszefüggést mértünk. A különbség magyarázható az eltérô térd- és kézkisízületi érintettséggel, de az is okozhatja, hogy a betegek a térd-, illetve a kézkisízületi osteoarthrosis miatti funkcióvesztést különbözőképpen ítélik meg.

- A funkcionális és életminőségtesztek kiemelt fontosságúak a generalizált osteoarthrosis betegségterhének felmérésében, a betegek állapotának megítélésében és a betegség megismerésében. A teszteket a mindennapi gyakorlatban is alkalmazni kell.

Anyagi támogatás: A közlemény megírása, illetve a kapcsolódó kutatómunka anyagi támogatásban nem részesült.

Szerzői munkamegosztás: K. E.: A vizsgálat tervezése és menetének követése, a beteg- és kontrollcsoport kialakítása, a vizsgálatba bevont személyek vizsgálata, adatok rögzítése, az eredmények elemzése és értelmezése, a kézirat megírása és véglegesítése. K. A.: A statisztikai analízis elkészítése, az eredmények értelmezése, a kézirat megírása és véglegesítése. K. Zs.: A beteg- és kontrollcsoport kialakítása, a vizsgálatba bevont személyek vizsgálata, a végleges kézirat elfogadása. K. R., P. Gy, Sz. M.: A vizsgálat tervezése, a végleges kézirat elfogadása. M. P.: Az eredmények értelmezése, a kézirat megírása és véglegesítése. B. G. P.: A vizsgálat tervezése, az eredmények értel- mezése, a kézirat megírása és véglegesítése. B. P. V.: A vizsgálat tervezése és vezetése, a beteg- és a kontrollcsoport kialakítása, a vizsgálatba bevont személyek vizsgálata, az eredmények értelmezése, a kézirat megírása és véglegesítése. A cikk végleges változatát valamennyi szerző elolvasta és jóváhagyta.

Érdekeltségek: A szerzőknek nincsenek érdekeltségeik.

\section{Köszönetnyilvánítás}

Köszönettel tartozunk a vizsgálatban részt vevőknek.

\section{Irodalom}

[1] Bitton R. The economic burden of osteoarthritis. Am J Manag Care 2009; 15(Suppl): S230-S235.

[2] Glyn-Jones S, Palmer AJ, Agricola R, et al. Osteoarthritis. Lancet 2015; 386: 376-387.

[3] Woolf AD, Pfleger B. Burden of major musculoskeletal conditions. Bull World Health Organ. 2003; 81: 646-656.

[4] Kadam UT, Jordan K, Croft PR. Clinical comorbidity in patients with osteoarthritis: a case-control study of general practice consulters in England and Wales. Ann Rheum Dis. 2004; 63: 408414.

[5] Valderas JM, Starfield B, Sibbald B, et al. Defining comorbidity: implications for understanding health and health services. Ann Fam Med. 2009; 7: 357-363.

[6] Jämsen E, Peltola M, Eskelinen A, et al. Comorbid diseases as predictors of survival of primary total hip and knee replacements: a nationwide register-based study of 96754 operations on patients with primary osteoarthritis. Ann Rheum Dis. 2013; 72: 1975-1982.

[7] Marengoni A, Angleman S, Melis R, et al. Aging with multimorbidity: a systematic review of the literature. Ageing Res Rev. 2011; 10: 430-439.

[8] Agborsangaya CB, Majumdar SR, Sharma AM, et al. Multimorbidity in a prospective cohort: prevalence and associations with weight loss and health status in severely obese patients. Obesity (Silver Spring) 2015; 23: 707-712.

[9] Nigro E, Scudiero O, Monaco ML, et al. New insight into adiponectin role in obesity and obesity-related diseases. Biomed Res Int. 2014; 2014: 658913.

[10] Salive ME. Future research directions for multimorbidity involving cardiovascular diseases. Clin Geriatr Med. 2016; 32: 399407.

[11] Altman R, Alarcon G, Appelrouth D, et al. The American College of Rheumatology criteria for the classification and reporting of osteoarthritis of the hand. Arthritis Rheum. 1990; 33: 16011610 .

[12] Altman R, Asch E, Bloch D, et al. Development of criteria for the classification and reporting of osteoarthritis. Classification of osteoarthritis of the knee. Diagnostic and Therapeutic Criteria Committee of the American Rheumatism Association. Arthritis Rheum. 1986; 29: 1039-1049.

[13] Clinical Guidelines on the identification, evaluation, and treatment of overweight and obesity in adults - the evidence report. National Institutes of Health. Obes Res. 1998; 6(Suppl 2): 51S-209S. [Correction: Obes Res. 1998; 6: 464.]

[14] Addimanda O, Mancarella L, Dolzani P, et al. Clinical associations in patients with hand osteoarthritis. Scand J Rheumatol. 2012; 41: 310-313

[15] Haugen IK, Ramachandran VS, Misra D, et al. Hand osteoarthritis in relation to mortality and incidence of cardiovascular disease: data from the Framingham Heart Study. Ann Rheum Dis. 2015 ; 74: 74-81. 
[16] Chung WS, Lin HH, Ho FM, at al. Risks of acute coronary syndrome in patients with osteoarthritis: a nationwide populationbased cohort study. Clin Rheumatol. 2016; 35: 2807-2813.

[17] Dougados M, Soubrier M, Antunez A, et al. Prevalence of comorbidities in rheumatoid arthritis and evaluation of their monitoring: results of an international, cross-sectional study (COMORA). Ann Rheum Dis. 2014; 73: 62-68.

[18] Kovari E, Kaposi A, Bekes G, et al. Comorbidity clusters in generalized osteoarthritis among female patients: a cross-sectional study. Semin Arthritis Rheum. 2020; 50: 183-191.

[19] Bellamy N, Buchanan WW, Goldsmith $\mathrm{CH}$, at al. Validation study of WOMAC: a health status instrument for measuring clinically important patient relevant outcomes to antirheumatic drug therapy in patients with osteoarthritis of the hip or knee. J Rheumatol. 1988; 15: 1833-1840.

[20] Poiraudeau S, Chevalier X, Conrozier T, et al. Reliability, validity, and sensitivity to change of the Cochin hand functional disability scale in hand osteoarthritis. Osteoarthritis Cartilage 2001; 9: 570-577.

[21] Bruce B, Fries JF. The Stanford Health Assessment Questionnaire: dimensions and practical applications. Health Qual Life Outcomes 2003; 1: 20.

[22] Douglas-Withers J, McCulloch K, Waters D, et al. Associations between Health Assessment Questionnaire Disability Index and physical performance in rheumatoid arthritis and osteoarthritis. Int J Rheum Dis. 2019; 22: 417-424.

[23] EuroQol Group. EuroQol - a new facility for the measurement of health-related quality of life. Health Policy 1990; 16: 199208.

[24] Dolan P. Modeling valuations for EuroQol health states. Med Care 1997; 35: 1095-1108.

[25] Schellevis FG, van der Velden J, van de Lisdonk E, et al. Comorbidity of chronic diseases in general practice. J Clin Epidemiol. 1993; 46: 469-473

[26] Xie F, Kovic B, Jin X, et al. Economic and humanistic burden of osteoarthritis: a systematic review of large sample studies. Pharmacoeconomics 2016; 34: 1087-1100.

[27] Wu M, Brazier JE, Kearns B, et al. Examining the impact of 11 long-standing health conditions on health-related quality of life using the EQ-5D in a general population sample. Eur J Health Econ. 2015; 16: 141-151.

[28] Xuan J, Kirchdoerfer LJ, Boyer JG, et al. Effects of comorbidity on health-related quality-of-life scores: an analysis of clinical trial data. Clin Ther. 1999; 21: 383-403.

[29] Teirlinck CH, Dorleijn DM, Bos PK, et al. Prognostic factors for progression of osteoarthritis of the hip: a systematic review. Arthritis Res Ther. 2019; 21: 192.

[30] Xu X, Mishra GD, Jones M. Evidence on multimorbidity from definition to intervention: an overview of systematic reviews. Ageing Res Rev. 2017; 37: 53-68.

[31] Vitaloni M, Botto-van Bemden A, Sciortino Contreras RM, et al. Global management of patients with knee osteoarthritis begins with quality of life assessment: a systematic review. BMC Musculoskelet Disord. 2019; 20: 493.

[32] Kim I, Kim HA, Seo YI, et al. Tibiofemoral osteoarthritis affects quality of life and function in elderly Koreans, with women more adversely affected than men. BMC Musculoskelet Disord. 2010; 11: 129.

[33] Gonçalves RS, Pinheiro JP, Cabri J. Evaluation of potentially modifiable physical factors as predictors of health status in knee osteoarthritis patients referred for physical therapy. Knee 2012; 19: 373-379.

[34] Agborsangaya CB, Ngwakongnwi E, Lahtinen M, et al. Multimorbidity prevalence in the general population: the role of obesity in chronic disease clustering. BMC Public Health 2013; 13: 1161.

[35] Divo MJ, Martinez CH, Mannino DM. Ageing and the epidemiology of multimorbidity. Eur Respir J. 2014; 44: 1055-1068.

[36] Kolotkin RL, Andersen JR. A systematic review of reviews: exploring the relationship between obesity, weight loss and healthrelated quality of life. Clin Obes. 2017; 7: 273-289.

[37] Xu X, Mishra GD, Dobson AJ, et al. Short-term weight gain is associated with accumulation of multimorbidity in mid-aged women: a 20-year cohort study. Int J Obes (Lond). 2019; 43: $1811-1821$

[38] Sullivan PW, Ghushchyan VH, Bayliss EA. The impact of comorbidity burden on preference-based health-related quality of life in the United States. Pharmacoeconomics 2012; 30: 431442.

[39] Piccirillo JF, Vlahiotis A, Barrett LB, et al. The changing prevalence of comorbidity across the age spectrum. Crit Rev Oncol Hematol. 2008; 67: 124-132.

[40] Sakib MN, Shooshtari S, St John P, et al. The prevalence of multimorbidity and associations with lifestyle factors among middleaged Canadians: an analysis of Canadian Longitudinal Study on Aging data. BMC Public Health 2019; 19: 243.

[41] Kiadaliri AA, Lamm CJ, de Verdier MG, et al. Association of knee pain and different definitions of knee osteoarthritis with health-related quality of life: a population-based cohort study in southern Sweden. Health Qual Life Outcomes 2016; 14: 121.

[42] Violan C, Foguet-Boreu Q, Flores-Mateo G, et al. Prevalence, determinants and patterns of multimorbidity in primary care: a systematic review of observational studies. PLoS ONE 2014; 9: el02149.

[43] de Carvalho JN, de Camargo Cancela M, de Souza DL. Lifestyle factors and high body mass index are associated with different multimorbidity clusters in the Brazilian population. PLoS ONE 2018; 13: e0207649.

(Kövári Eszter dr., Budapest, Mester u. 83/C, 3. em. 12., 1095 e-mail: ester.kovari@gmail.com)

A cikk a Creative Commons Attribution 4.0 International License (https://creativecommons.org/licenses/by/4.0/) feltételei szerint publikált Open Access közlemény, melynek szellemében a cikk bármilyen médiumban szabadon felhasználható, megosztható és újraközölhető, feltéve, hogy az eredeti szerző és a közlés helye, illetve a CC License linkje és az esetlegesen végrehajtott módosítások feltüntetésre kerülnek. (SID_1) 